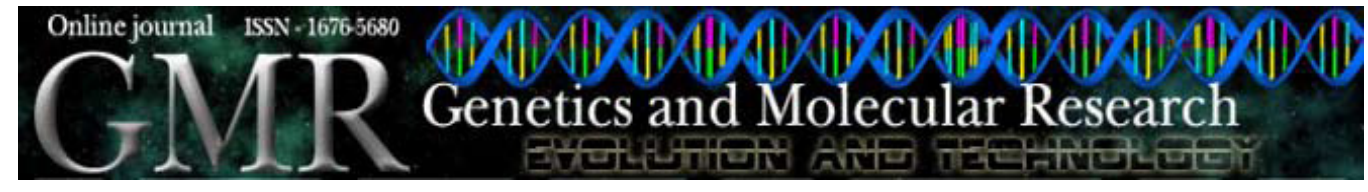

\title{
Genetic characterization of pea (Pisum sativum) germplasm from Turkey using morphological and SSR markers
}

\author{
G. Sarıkamış ${ }^{1}$, R. Yanmaz', S. Ermiş², M. Bakır ${ }^{3}$ and C. Yüksel ${ }^{3}$ \\ ${ }^{1}$ Department of Horticulture, Faculty of Agriculture, \\ Ankara University, Ankara, Turkey \\ ${ }^{2}$ Variety Registration and Seed Certification Centre/MARA, \\ Yenimahalle, Ankara, Turkey \\ ${ }^{3}$ Biotechnology Institute, Ankara University, Ankara, Turkey \\ Corresponding author: G. Sarıkamış \\ E-mail: golges@yahoo.com
}

Genet. Mol. Res. 9 (1): 591-600 (2010)

Received December 10, 2009

Accepted January 15, 2010

Published March 30, 2010

\begin{abstract}
The need for the conservation of plant genetic resources has been widely accepted. Germplasm characterization and evaluation yield information for more efficient utilization of these valuable resources. The aim of the present study was to characterize the pea germplasm conserved at the Aegean Agricultural Research Institute of Turkey using morphological and simple sequence repeat (SSR)-based molecular approaches. Genetic characterization of 30 pea genotypes collected from different regions of Turkey and 10 commercial pea cultivars was performed using the criteria of the International Union for the Protection of New Varieties of Plants (UPOV) (TG 7/9 Pisum sativum), and with 10 SSR markers. We originally tested 15 SSR markers; 10 of these markers were selected on the basis of high polymorphism information content in the molecular assays. Sixty-one alleles were detected at the 10 loci. The number of alleles per SSR locus ranged from 3 (PVSBE2) to 12 (AB53), with a mean of 6.1 alleles. The most informative loci were AB53 (12 alleles), AA355 (9 alleles), AD270 (8 alleles), A9 (7 alleles), AD61 (7 alleles), and AB25 (6 alleles). The UPGMA dendrogram defined by
\end{abstract}


SSR markers revealed genetic relatedness of the pea genotypes. These findings can be used to guide future breeding studies and germplasm management of these pea genotypes.

Key words: Pea; Pisum sativum; Simple sequence repeat; Morphology; Genetic characterization

\section{INTRODUCTION}

Pea (Pisum sativum L.) is an important legume grown and consumed extensively worldwide. As a rich source of proteins, carbohydrates and vitamins, peas are important in human nutrition. Consumed mostly as green peas, total production worldwide is around 8.3 million tons (FAO, 2008). Pea is the fourth leading legume in terms of consumption in the world and is the second most important legume after common bean (Phaseouls vulgaris L.) in Turkey with a total production of 88,828 tons (FAO, 2008).

Endowed with a rich diversity of families (163), genera (1225) and species (9000) of plants, Turkey is one of the centers of origin and/or diversity of several crop plants, and many plant species (Tan, 1998; Özgen et al., 2000). Turkey is also the center of origin and genetic diversity of many wild, transitional, and cultivated forms of annual and perennial, herbaceous and woody plants such as the cultivated species of Allium, Amygdalus, Avena, Beta, Cicer, Hordeum, Lens, Linum, Pisum, Prunus, Secala, Triticum, and Vitis (Tan, 1998).

In order to preserve these genetic resources, several crop species from different geographical regions of Turkey are collected and preserved. One such institution is the Aegean Agricultural Research Institute of the Ministry of Agricultural and Rural Affairs, which has a collection of plant genetic resources belonging to several crop species. This collection includes pea genotypes obtained from different geographical regions of Turkey.

The aim of the present study was to assess the level of genetic diversity within this collection of pea genotypes to aid in the selection and more efficient utilization of this germplasm in breeding programs.

Several studies have been carried out to study genetic diversity within the pea germplasm and wild and cultivated species using different approaches (Samec and Našinec, 1995; Hoey et al., 1996; Zong et al., 2008a,b). In addition to morphological and biochemical traits, molecular markers (Smýkal et al., 2008) have been used for the identification of genetic relationships and exploring diversity. Molecular markers have enormous potential to explore genetic diversity by detecting polymorphisms to improve the efficiency and precision of conventional plant breeding. Using random amplified polymorphic DNA (RAPD) markers, significant differences were identified between and within wild and cultivated pea species (Samec and Našinec, 1995; Hoey et al., 1996). Amplified fragment length polymorphism (AFLP) markers were also used for detecting polymorphisms within pea genotypes (Simioniuc et al., 2002). Among the most widely used markers in crop species are simple sequence repeats (SSRs) or microsatellites (Blair et al., 2007; Sarıkamış et al., 2009). They are highly reliable because they are reproducible, co-dominant in inheritance and generally highly polymorphic.

However, SSR markers require a substantial investment of time and money to develop, and hence, adequate numbers for high-density mapping are not available for some 
crop species. Significant effort has been dedicated to their development in various species during the last decade. They are now widely used for investigating genetic diversity among cultivars and genetic resources, and for developing genetic maps suitable for quantitative trait loci (QTL) detection and marker-assisted selection programs. In pea, comprehensive consensus linkage maps integrating linkage relationships from multiple maps and linkage studies (Weeden et al., 1998; Ellis and Poyser, 2002; Loridon et al., 2005) located several anonymous SSRs and their map positions for broad application of these markers as a common set for genetic studies in pea.

In this study, genetic diversity of pea genotypes collected from different regions of Turkey and preserved at the Aegean Research Institute Gene Bank was performed using morphological and SSR markers. This information could greatly assist in the identification, breeding and preservation of the pea germplasm.

\section{MATERIAL AND METHODS}

\section{Plant material}

The germplasm used in this study consisted of 30 pea (Pisum sativum L.) genotypes obtained from the Gene Bank of the Aegean Research Institute of the Turkish Ministry of Agricultural and Rural Affairs. The collection site of each pea genotype is shown in Figure 1. Ten commercial cultivars (Rondo, Utrillo, Sprinter, Spring, Television, Karina, Bolero, Sorgun, Jof, Senador Cambados) were used as reference cultivars in SSR analysis. Pea genotypes assessed by morphological and molecular markers in the present study were grown in the experimental plots of the Department of Horticulture, Faculty of Agriculture, Ankara University. The seeds were sown directly in the field when soil temperature increased to $7^{\circ} \mathrm{C}$, leaving 60 $\mathrm{cm}$ between rows and $15 \mathrm{~cm}$ between plants. Standard cropping practices were used during the growth period. The experiment was performed during 2006 and 2007.

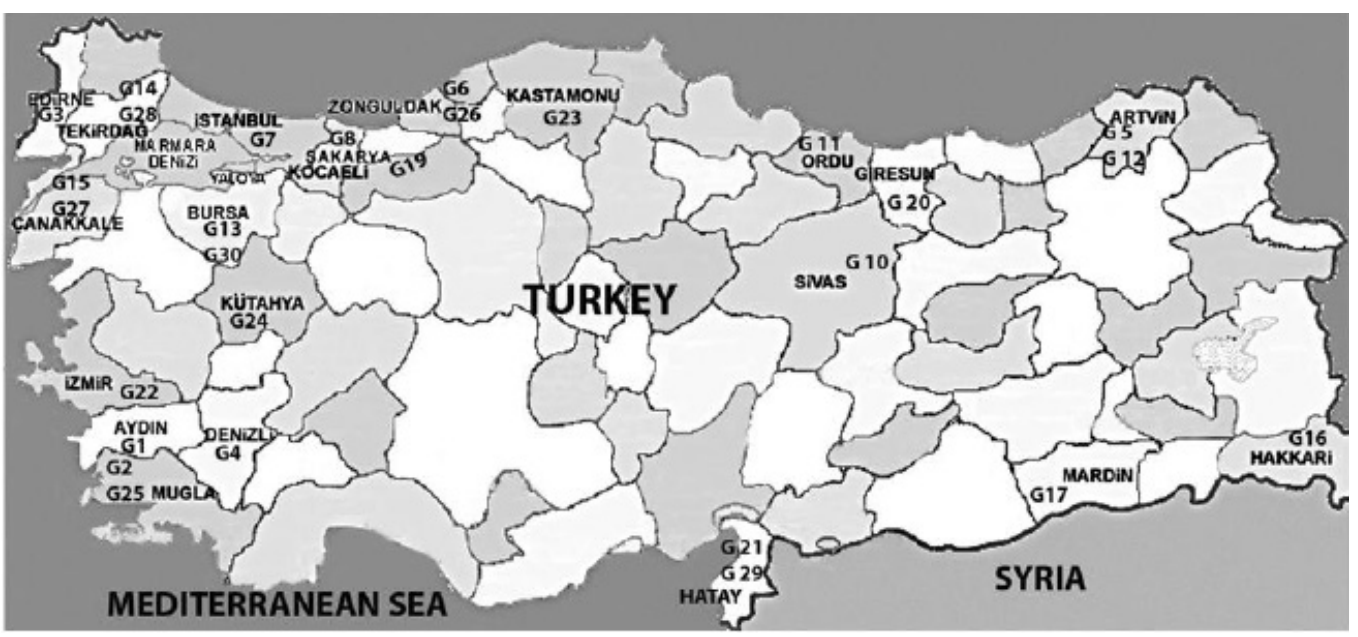

Figure 1. Map of Turkey indicating pea collection sites. Each genotype is labeled on the map. 


\section{Morphological characterization}

Morphological characteristics of 30 pea genotypes were determined on 10 randomly selected plants per genotype. A total of 72 morphological traits including plant, stem, leaf and leaflet, wing, stipule, flower, pod characters, and the occurrence of pests and diseases were evaluated according to the guidelines provided by the International Union for the Protection of New Varieties of Plants (UPOV, 1990) (TG 7/9 Pisum sativum L.).

However, only certain characters regarding plant, stipule, flowering time, pod, and seed traits required for variety discrimination according to UPOV and that revealed polymorphisms among genotypes were selected and presented in the current study (Table 1). Morphological characteristics of the commercial pea cultivars were obtained from cultivar catalogue information.

\section{Molecular characterization}

Genomic DNA was extracted from young leaf tissues using Promega ${ }^{\circledR}$ DNA Extraction Kit. The extraction was carried out according to the protocol of the manufacturer. Subsequently, the eluted DNA samples were treated with RNAse. DNA quality and quantity were assessed on a $1 \%(\mathrm{w} / \mathrm{v})$ agarose gel stained with ethidium bromide. Quantity was then checked using a NanoDrop ${ }^{\circledR}$ ND-1000 Spectrophotometer. A total of 15 SSR markers were selected to detect polymorphisms and assess genetic diversity of the germplasm: 7 originated from a pea genetic map constructed by Loridon et al. (2005) (http://dx.doi. org/10.1007/s00122-005-0014-3) from the Pea Microsatellite Consortium, and 8 originated from common bean, which were previously used to characterize common bean genotypes (Sarıkamış et al., 2009) and hence already at hand to enrich the study. The selection of 7 pea SSRs was based on their high polymorphism information content and the quality scores reported (Loridon et al., 2005). Primers revealing clear single-band patterns were preferred. However, only 10 SSR markers ( 7 pea SSRs and 3 bean SSRs) were considered for molecular characterization of genotypes. The list of primer pairs used and the relevant information are presented in Table 2.

Polymerase chain reaction (PCR) mixture contained $15 \mathrm{ng}$ DNA, 5 pmol of each primer, $0.5 \mathrm{mM}$ dNTP, 0.5 U GoTaq DNA polymerase (Promega, Madison, WI, USA), 1.5 $\mathrm{mM} \mathrm{MgCl}, 2 \mu \mathrm{L} 5 \mathrm{X}$ buffer in a volume of $10 \mu \mathrm{L}$. The forward primers were labeled with WellRED fluorescent dyes D2 (black), D3 (green) and D4 (blue) (Sigma). Reaction mixtures without DNA were included as negative controls. PCR amplification was performed using the Biometra ${ }^{\circledR}$ PCR System. The amplification conditions involved an initial step of 3 min at $94^{\circ} \mathrm{C}$, followed by 35 cycles of $1 \mathrm{~min}$ at $94^{\circ} \mathrm{C}, 1 \mathrm{~min}$ at $52-56^{\circ} \mathrm{C}$ and $2 \mathrm{~min}$ at $72^{\circ} \mathrm{C}$, with a final extension at $72^{\circ} \mathrm{C}$ for $10 \mathrm{~min}$. PCR products were first separated on a $3 \%(\mathrm{w} / \mathrm{v})$ agarose gel stained with ethidium bromide at a concentration of $10 \mathrm{mg} / \mathrm{mL}$ and run at 80 volts for $2 \mathrm{~h}$. DNA Ladder (100 bp) (Promega) was used for the approximate quantification of the bands. The products were visualized under UV light and sized relative to the ladder. For further determination of polymorphisms, the PCR products were run on a CEQ 8800 XL capillary DNA Analysis System (Beckman Coulter, Fullerton, CA, USA). The analyses were repeated at least twice to ensure reproducibility of the results. Allele sizes were determined for each SSR locus using the Beckman CEQ fragment analysis software. 


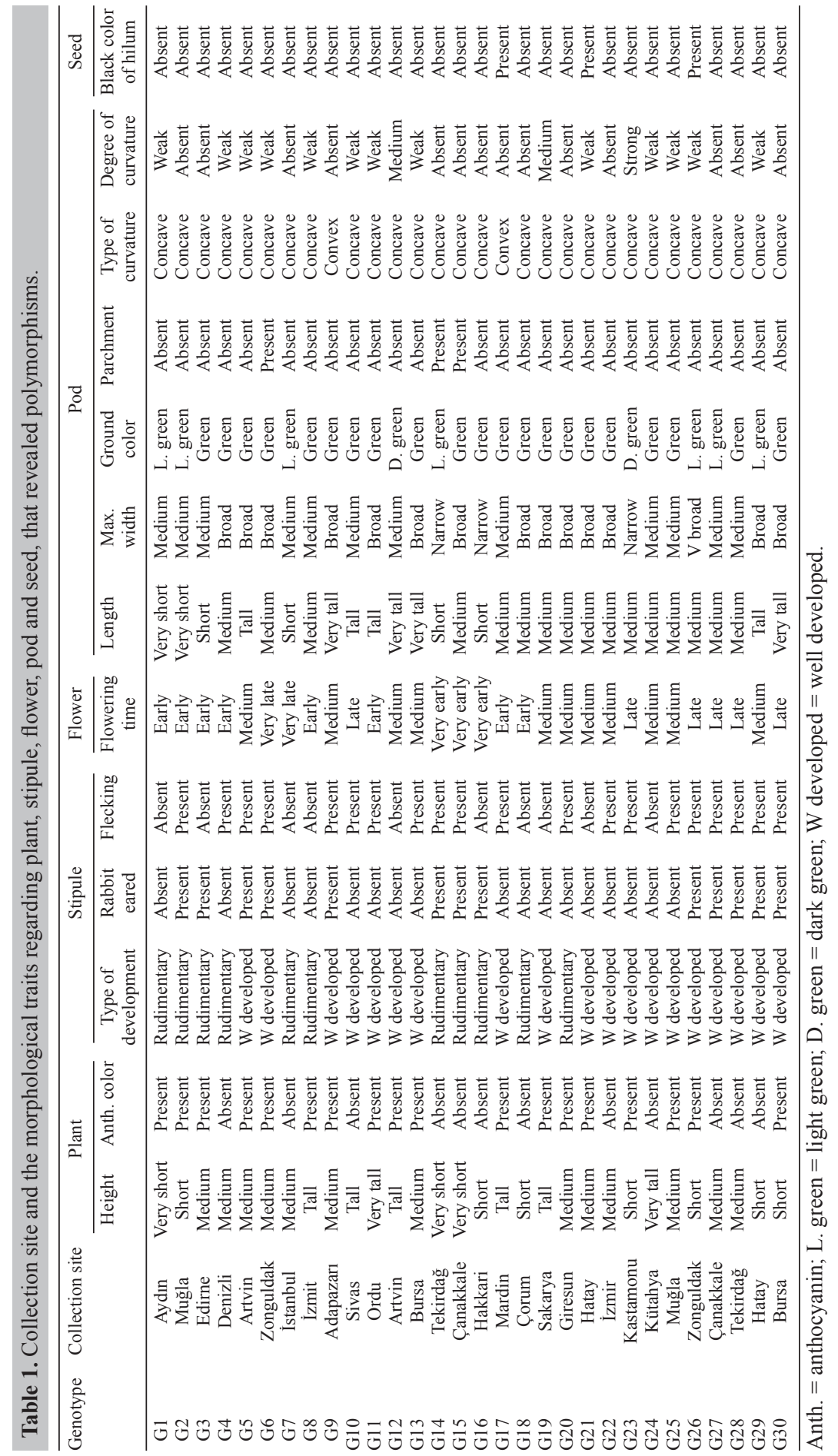




\section{Genetic analysis}

The genetic analysis "IDENTITY" 1.0 program (Wagner and Sefc, 1999) according to Paetkau et al. (1995) was used for the calculation of number of alleles, allele frequency, expected and observed heterozygosity, estimated frequency of null alleles, and probability of identity per locus. Genetic dissimilarity was determined by the "MICROSAT" program, version 1.5 (Minch et al., 1995) using proportion of shared alleles, which was calculated using ps (option 1 - (ps)) as described by Bowcock et al. (1994). The results were then converted to a similarity matrix and a dendogram was constructed with UPGMA (unweighted pair-group method with arithmetic mean) (Sneath and Sokal, 1973), using the NTSYS-pc software (Numerical Taxonomy and Multiware Analysis System, version 2.0 (Rohlf, 1988).

\section{RESULTS}

\section{Morphological characterization}

The origin (collection site) and a summary of the morphological traits that revealed polymorphisms are presented in Table 1 . When seeds were considered, black color of hilum was only present in G17, G21 and G26. In terms of plant height, 10\% of genotypes were categorized as very short, $23 \%$ as short, $43 \%$ as medium, $17 \%$ as tall, and $7 \%$ as very tall plants. The presence of anthocyanin coloration was evident in $60 \%$ of genotypes. Variation in terms of pod characters such as pod length, maximum width, ground color, parchment, degree of curvature, and type of curvature was observed. Pod ground color was mostly green (70\%), but in some, it was light green (G1, G2, G7, G14, G26, G27, and G29) and in one case (G23) dark green. Parchment was present only in three genotypes (G6, G14 and G15). Degree of curvature varied being mostly concave except the genotypes G9 and G17. The stipule was mostly well developed, but in some it was rudimentary. Rabbit-eared stipules were present in $47 \%$ and was absent in $53 \%$ of the genotypes. Flecking was present in the majority (67\%) but absent in some genotypes $(33 \%)$. Variation in terms of flowering time was observed. However, no differences in leaf color and pod shape were observed among the genotypes, and hence, these characters are not presented in Table 1.

\section{Molecular characterization}

Seven microsatellite markers selected on the basis of high polymorphism information content (Loridon et al., 2005) revealed successful amplifications of expected allele sizes (Table 2). Among a total of eight common bean SSR markers (Yu et al., 2000) selected on the basis of high polymorphism information content, only three markers (PV-at002, PV-at006 and PVSBE2) were used for characterization due to their reliable amplification patterns. Therefore, genetic diversity within the collection of 30 pea genotypes together with 10 commercial pea cultivars was assessed by 10 SSR markers. In all, a total of 61 alleles were detected at the 10 SSR loci analyzed. The number of alleles per SSR locus ranged from 3 (PVSBE2) to 12 (AB53) with an average of 6.1 alleles, while one of the primers was monomorphic (PV-at006). 
Table 2. Allele range values (bp), number of alleles, expected heterozygosity, observed heterozygosity, frequency of null alleles and probability of identity values of pea genotypes calculated at 10 simple sequence repeat loci.

\begin{tabular}{|c|c|c|c|c|c|c|}
\hline Locus & $\begin{array}{c}\text { Allele } \\
\text { range (bp) }\end{array}$ & $\begin{array}{l}\text { Number of } \\
\text { alleles }\end{array}$ & $\begin{array}{c}\text { Expected } \\
\text { heterozygosity }\end{array}$ & $\begin{array}{c}\text { Observed } \\
\text { heterozygosity }\end{array}$ & $\begin{array}{l}\text { Frequency of } \\
\text { null alleles }\end{array}$ & $\begin{array}{c}\text { Probability of } \\
\text { identity }\end{array}$ \\
\hline $\begin{array}{l}\text { AA205 } \\
\text { (P. sativum) } \\
\text { AD270 }\end{array}$ & $180-238$ & 4 & 0.629 & 0.100 & 0.324 & 0.306 \\
\hline $\begin{array}{l}\text { (P. sativum) } \\
\text { AB25 }\end{array}$ & $283-313$ & 8 & 0.787 & 0.000 & 0.440 & 0.128 \\
\hline $\begin{array}{l}\text { (P. sativum) } \\
\text { AB53 }\end{array}$ & $182-232$ & 6 & 0.671 & 0.000 & 0.401 & 0.235 \\
\hline $\begin{array}{l}\text { (P. sativum) } \\
\text { A9 }\end{array}$ & $88-148$ & 12 & 0.820 & 1.000 & -0.098 & 0.099 \\
\hline $\begin{array}{l}\text { (P. sativum) } \\
\text { AA355 }\end{array}$ & $360-384$ & 7 & 0.651 & 0.050 & 0.364 & 0.229 \\
\hline $\begin{array}{l}\text { (P. sativum) } \\
\text { AD61 }\end{array}$ & $184-232$ & 9 & 0.760 & 0.175 & 0.332 & 0.157 \\
\hline $\begin{array}{l}\text { (P. sativum) } \\
\text { PV-at002 }\end{array}$ & $113-135$ & 7 & 0.820 & 0.050 & 0.423 & 0.106 \\
\hline $\begin{array}{l}\text { (P. vulgaris) } \\
\text { PV-at006 }\end{array}$ & $247-367$ & 4 & 0.601 & 0.450 & 0.094 & 0.354 \\
\hline $\begin{array}{l}\text { (P. vulgaris) } \\
\text { PVSBE2 }\end{array}$ & 368 & 1 & 0.000 & 0.000 & 0.000 & 1.000 \\
\hline (P. vulgaris) & $113-133$ & 3 & 0.324 & 0.350 & -0.019 & 0.591 \\
\hline
\end{tabular}

The number of alleles suggested that the most informative loci were AB53 (12 alleles), AA355 (9 alleles), AD270 (8 alleles), A9 (7 alleles), AD61 (7 alleles), AB25 (6 alleles). Contrarily, the least informative loci were AA205 (4 alleles), PV-at002 (4 alleles) and PVSBE2 (3 alleles). One of the primers (PV-at006) was monomorphic (Table 2). Probability of identity values were generally greater than 0.05 (Sefc et al., 2001).

The closest genetic relationship was observed between the two genotypes G13 and G25 (0.900), followed by G9-G23 (0.850) and G30-Sprinter (0.800). While the genetic similarity between the cultivars Utrillo and Senador was 0.950 , the similarity of these two to Sorgun was 0.900 .

The UPGMA dendrogram (Figure 2) as defined by SSR markers revealed two main groups. While genotypes G2 and G27 clustered as one major group (group 1), pea cultivars and the rest of genotypes formed a separate group (group 2). A single genotype (G30) originating from Bursa was closely related to Sprinter, a commercial pea cultivar. Subsequently, group 2 was further divided into several subgroups containing the remaining genotypes and cultivars. Genotypes G3, G12 and G22 were related to Rondo and Bolero with a similarity index of around 0.45 .

\section{DISCUSSION}

The present study revealed the genetic diversity within a collection of pea germplasm representing different geographical regions of Turkey, using morphological and molecular (SSR) approaches (Figure 2).

Assessment of genetic variability within a germplasm is of interest for practical applications such as conservation of genetic resources and for breeding purposes, to predict the ability to combine or to rapidly verify the breeding material. Hence, it is crucial for genetic improvement and elite gene exploitation, such as tolerance genes to abiotic stresses. 


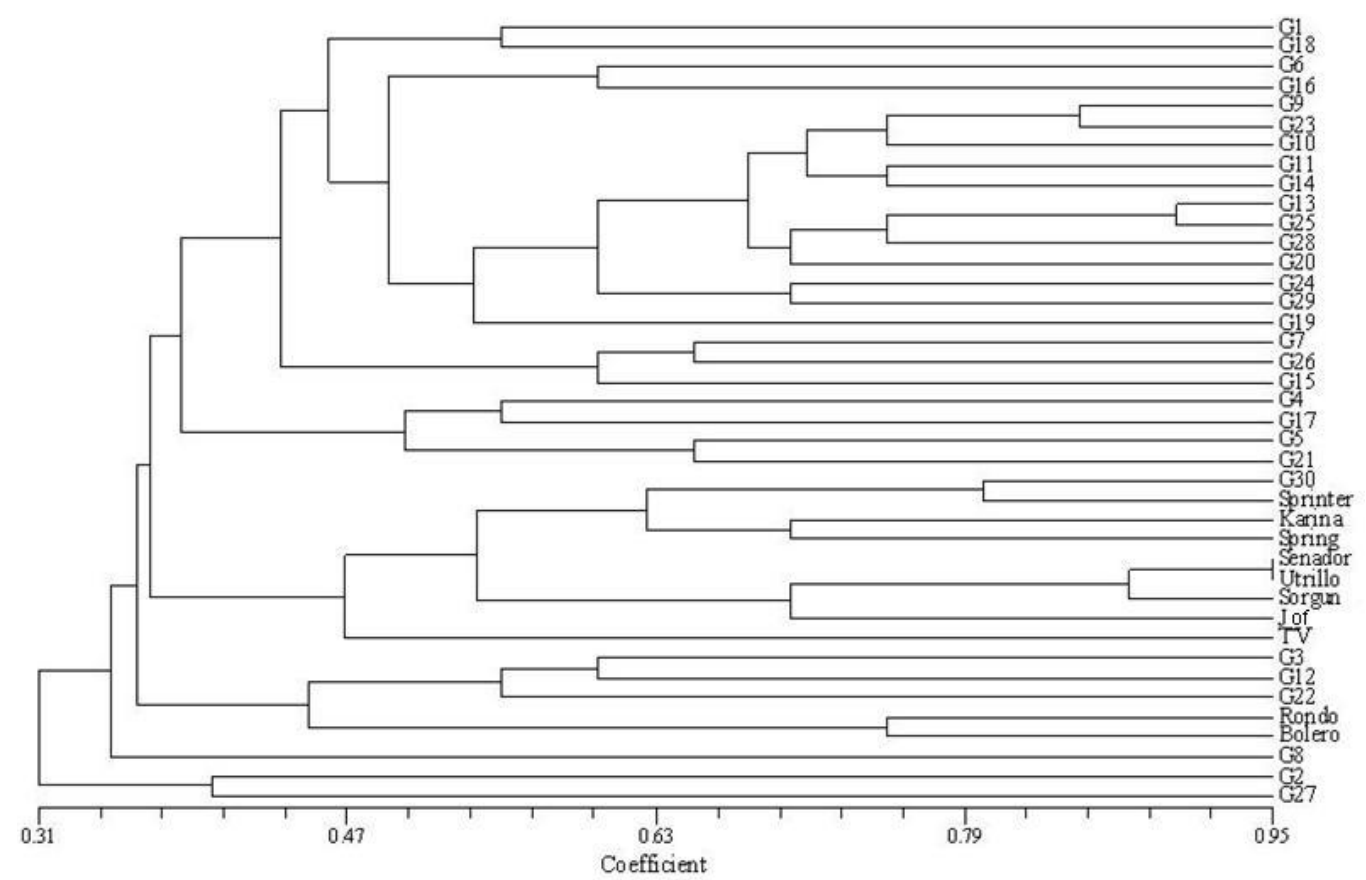

Figure 2. Dendrogram showing the genetic relationships of 30 pea genotypes together with 10 commercial pea cultivars based on the UPGMA cluster analysis of 10 simple sequence repeat marker data.

Within the collection studied, variation was observed in terms of seed, plant, pod, stipule, flower characteristics, and flowering time, which are important traits for the identification, characterization and grouping of genotypes. Morphological characterization has long been performed in many plant species either on its own or in combination with biochemical and/or molecular assays (Duran et al., 2005; Smýkal et al., 2008).

However, for the majority of traits, interactions between genotype and environment complicate the evaluation process. Molecular markers have the potential to facilitate this procedure, increase the reliability of decisions, and substantially save time.

Several different marker systems (isozymes, restriction fragment length polymorphisms (RFLPs), AFLPs) have been used for either mapping studies or diversity assessment in pea. However, few studies have used SSR markers (Weeden et al.,1998; Burstin et al., 2001; Pilet-Nayel et al., 2002; Baranger et al., 2004; Prioul et al., 2004; Tar'an et al., 2005; Zong et al., 2008a,b). SSR markers were reported as superior in terms of high information content and discrimination power owing to high allelic variation, allowing clear identification of all varieties compared to most DNA as well as biochemical and morphological markers (Smýkal et al., 2008). Primers used in the present study were selected among a set of microsatellite markers developed for the Pea Microsatellite Consortium (Loridon et al., 2005).

All 7 primers consistently revealed a clear banding pattern in all samples analyzed. However, when common bean primers were used to amplify pea genomic DNA, only three primers displayed clear banding patterns, while the rest of the primers either revealed a multiple band pattern, non-reproducible bands or no product and discarded after several attempts 
to improve PCR conditions. Overall, 10 successful SSR loci yielding bands of expected sizes were utilized for characterization and provided precise identification of all genotypes. The average number of alleles obtained in the present study is in agreement with results obtained by Loridon et al. (2005). Observed heterozygosity was generally lower than expected, except for AB53 and PVSBE2. This is probably due to the inbreeding nature of pea but not due to null alleles. The UPGMA dendrogram clearly demonstrated the genetic relationship among genotypes and reference cultivars. Taken together, the closely linked genotypes were also closely related in terms of the morphological traits presented.

However, no ecogeographical distribution was observed within the subgroups.

\section{CONCLUSION}

The need for the conservation of plant genetic resources has been widely accepted. Germplasm characterization and evaluation complemented by molecular studies generate the information base for more efficient utilization of these valuable resources by gene bank managers, plant breeders and research scientists to focus on the search for desirable new characters. Utilization of plant genetic resources following a network approach with effective connections between the national gene bank and researchers must be encouraged. The present study aimed to characterize the pea germplasm maintained at the Aegean Research Institute Gene Bank of Turkey using morphological and molecular approaches. The results may offer scope for pea breeding programs aimed to generate new improved cultivars in the future.

\section{ACKNOWLEDGMENTS}

The authors would like to thank Prof. Ali Ergül from the Biotechnology Institute, Ankara University for his kind help and support and the Aegean Agricultural Research Institute for kindly providing the seeds for this research.

\section{REFERENCES}

Baranger A, Aubert G, Arnau G, Laine AL, et al. (2004). Genetic diversity within Pisum sativum using protein- and PCRbased markers. Theor. Appl. Genet. 108: 1309-1321.

Blair MW, Diaz JM, Hidalgo R, Diaz LM, et al. (2007). Microsatellite characterization of Andean races of common bean (Phaseolus vulgaris L.). Theor. Appl. Genet. 116: 29-43.

Bowcock AM, Ruiz-Linares A, Tomfohrde J, Minch E, et al. (1994). High resolution of human evolutionary trees with polymorphic microsatellites. Nature 368: 455-457.

Burstin J, Deniot G, Potier J, Weinachter C, et al. (2001). Microsatellite polymorphism in Pisum sativum. Plant Breed. 120: 311-317.

Duran LA, Blair MW, Giraldo MC, Macchiavelli R, et al. (2005). Morphological and molecular characterization of common bean landraces and cultivars from the Caribbean. Crop Sci. 45: 1320-1328.

Ellis THN and Poyser SJ (2002). An integrated and comparative view of pea genetic and cytogenetic maps. New Phytol. 153: 17-25.

Food and Agriculture Organization of the United Nations (FAO) (2008). FAOSTAT. Available at [http://faostat.fao.org]. Accessed March 23, 2010.

Hoey BK, Crowe KR, Jones VM and Polans NO (1996). A phylogenetic analysis of Pisum based on morphological characters, and allozyme and RAPD markers. Theor. Appl. Genet. 92: 92-100.

International Union for the Protection of New Varieties of Plants (UPOV) (1990). Guidelines for the Conduct of Test for Distinctiveness, Uniformity and Stability. Document UPOV (TG 7/9 Pisum sativum L.), Geneva. 
Loridon K, McPhee K, Morin J, Dubreuil P, et al. (2005). Microsatellite marker polymorphism and mapping in pea (Pisum sativum L.). Theor. Appl. Genet. 111: 1022-1031.

Minch E, Ruiz-Linares A, Goldstein DB, Feldman M, et al. (1995). Microsat (Version 1.4d): a Computer Program for Calculating Various Statistics on Microsatellite Allele Data. Stanford University Medical Center, Stanford.

Özgen M, Adak MS, Söylemezoglu G and Ulukan H (2000). Bitkisel Gen Kaynaklarinin Korunma ve Kullaniminda Yeni Yaklasimlar (New approaches for the preservation and utilization of plant genetic resources). V. Türkiye Ziraat Müh. Kongresi (V. Agricultural Engineers Congress), Ankara, 259-284.

Paetkau D, Calvert W, Stirling I and Strobeck C (1995). Microsatellite analysis of population structure in Canadian polar bears. Mol. Ecol. 4: 347-354.

Pilet-Nayel L, Muehlbauer FJ, McGee RJ, Kraft JM, et al. (2002). Quantitative trait loci for partial resistance to Aphanomyces root rot in pea. Theor. Appl. Genet. 106: 28-39.

Prioul S, Frankewitz A, Deniot G, Morin G, et al. (2004). Mapping of quantitative trait loci for partial resistance to Mycosphaerella pinodes in pea (Pisum sativum L.), at the seedling and adult plant stages. Theor. Appl. Genet. 108: 1322-1334.

Rohlf FJ (1988). NTSYS-PC Numerical Taxonomy and Multivariate Analysis System. Exeter Publishing, New York.

Samec P and Našinec V (1995). Detection of DNA polymorphism among pea cultivars using RAPD technique. Biol. Plantarum 37: 321-327.

Sarikamiş G, Yasar F, Bakir M, Kazan K, et al. (2009). Genetic characterization of green bean (Phaseolus vulgaris) genotypes from eastern Turkey. Genet. Mol. Res. 8: 880-887.

Sefc KM, Lefort F, Grando MS, Scott KD, et al. (2001). Microsatellite Markers for Grapevine: A State of the Art. In: Molecular Biology and Biotechnology of the Grapevine (Roubelakis-Angelakis KA, ed.). Kluwer Academic Publishers, Netherlands, 1-29.

Simioniuc D, Uptmoor R, Friedt W and Ordon F (2002). Genetic diversity and relationships among pea cultivars revealed by RAPDs and AFLPs. Plant Breed. 121: 429-435.

Smýkal P, Horácèk J, Dostálová R and Hýbl M (2008). Variety discrimination in pea (Pisum sativum L.) by molecular, biochemical and morphological markers. J. Appl. Genet. 49: 155-166.

Sneath PH and Sokal RR (1973). Numerical Taxonomy. Freeman, San Francisco.

Tan A (1998). Current Status of Plant Genetic Resources Conservation in Turkey. In: The Proceeding of International Symposium on In situ Conservation of Plant Genetic Diversity (Zencirci N, Kaya Z, Anikster Y and Adams WT, eds.). November 4-8, 1996. Antalya, Turkey.

Tar'an B, Zhang C, Warkentin T, Tullu A, et al. (2005). Genetic diversity among varieties and wild species accessions of pea (Pisum sativum L.) based on molecular markers, and morphological and physiological characters. Genome 48: 257-272.

Wagner HW and Sefc KM (1999). Identity1.0. Centre for Applied Genetics. University of Agricultural Science, Vienna.

Weeden NF, Ellis THN, Timmerman-Vaughan GM, Sweicicki WK, et al. (1998). A consensus linkage map for Pisum sativum. Pisum Genet. 30: 1-4.

Yu K, Park SJ, Poysa V and Gepts P (2000). Integration of simple sequence repeat (SSR) markers into a molecular linkage map of common bean (Phaseolus vulgaris L.). J. Hered. 91: 429-434.

Zong XX, Guan JP, Wang SM and Liu QC (2008a). Genetic diversity among Chinese Pea (Pisum sativum L.) landraces as revealed by SSR markers. Acta Agron. Sinica 34: 1330-1338.

Zong XX, Guan JP, Wang SM, Liu QC, et al. (2008b). Genetic diversity and core collection of alien Pisum sativum L. germplasm. Acta Agron. Sinica 34: 1518-1528. 